\title{
Analysis of bovine caseins and primary hydrolysis products in cheese by capillary zone electrophoresis
}

\author{
J Otte, M Zakora, KR Kristiansen, KB Qvist
}

Department of Dairy and Food Science. The Royal Veterinary and Agricultural University, Rolighedsvej 30, DK-1958 Frederiksberg C, Denmark

\begin{abstract}
Summary - Casein fractions from milk and various cheeses as well as isolated casein standards were analysed by capillary electrophoresis under acidic conditions. Capillary electrophoresis was performed on a Waters Quanta 4000 apparatus with a hydrophilically coated or an untreated fused-silica capillary. The four major caseins in an acid precipitate from milk were well separated. In addition, the various phosphorylation states of the $\alpha_{\mathrm{s} 1}$ - and the $\alpha_{\mathrm{s} 2}$-caseins and some genetic variants of $\beta$-casein were separated. The major casein hydrolysis products formed in cheese, para- $\kappa$-casein, $\alpha_{\mathrm{s1}}$-casein-I and $\gamma$-caseins, were separated from their parent casein and from most other major caseins. The linearity of the method with respect to injection time and casein concentration was acceptable. With improved repeatability of peak areas the method should be superior to urea-PAGE and an attractive alternative to high-pressure liquid chromatography (HPLC) methods for following casein proteolysis in dairy products.
\end{abstract}

capillary electrophoresis / bovine casein / cheese

Résumé - Analyse des caséines bovines et des produits d'hydrolyse primaire du fromage par électrophorèse capillaire. Des fractions de caséine du lait et de divers fromages, ainsi que des standards de caséines isolées ont été analysés par électrophorèse capillaire en milieu acide. L'électrophorèse capillaire (EC) a été réalisée avec l'appareil Quanta 4000 de Waters, avec des capillaires traités par un polymère hydrophile et des capillaires en silice non traités. Les quatre caséines majeures d'un précipité acide du lait ont bien été séparées par l'EC. De plus, les caséines $\alpha_{\mathrm{s} 1}$ et $\alpha_{\mathrm{s} 2}$ avec un nombre de groupes phosphate variable et quelques variants génétiques de caséine $\beta$ ont été séparés. Leurs produits de dégradation principaux dans le fromage, caséines para- $\kappa, \alpha_{\mathrm{s1}}-\mathrm{I}$ et $\gamma$, ont été séparés de leur caséine originale et de la plupart des autres caséines. La linéarité de la méthode concernant la durée d'injection et la concentration des caséines étaient suffisantes. Avec une amélioration de la répétabilité des aires de pic, cette méthode serait meilleure que l'électrophorèse en gel de polyacrylamide en présence d'urée et représenterait une alternative intéressante aux méthodes de chromatographie liquide haute performance pour évaluer la protéolyse primaire des caséines des produits laitiers.

électrophorèse capillaire / caséine bovine / fromage

Oral communication at the IDF Symposium 'Ripening and Quality of Cheeses', Besançon, France, February 26-28, 1996. 


\section{INTRODUCTION}

Bovine milk contains four different caseins, $\alpha_{\mathrm{s} 1^{-}}, \alpha_{\mathrm{s} 2^{-}}, \beta$ - and $\kappa$-casein, three of them occurring as several genetic variants. The $\alpha_{\mathrm{s}}$-caseins, in addition, contain a varying number of serine phosphate groups (Swaisgood, 1992). During manufacture and ripening of cheese the caseins are broken down to various degrees, the extent of which is a major determinant of the texture and flavour of the cheese (Creamer and Olson, 1982; Fox et al, 1993). Cleavage of $\kappa$-casein catalysed by chymosin (EC. 3.4.23.4) leads to milk coagulation and formation of the cheese curd. Primary proteolysis of the caseins in the cheese is initiated by the action of the added chymosin on $\alpha_{\mathrm{sl}}$-casein and of the indigenous plasmin (EC. 3.4.21.7) on $\beta$-casein (Grappin et al, 1985; Exterkate and Alting, 1995). Further proteolysis during cheese ripening is catalysed mainly by proteases and peptidases released from starter and other bacteria (Fox et al, 1993). The main primary casein hydrolysis products reported to occur in cheese are listed in table I.

To characterise the casein proteolysis during cheese maturation, the $\mathrm{pH}$ 4.6-insoluble protein fraction of cheeses have been analysed by various methods (Grappin and
Ribadeau-Dumas, 1992). Traditional slab gel electrophoresis in urea containing media has the potential for resolution of all four major caseins as well as some of the

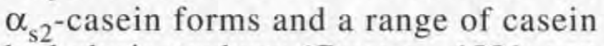
hydrolysis products (Creamer, 1991; van Hekken and Thompson, 1992; Centeno et al, 1994; McSweeney et al, 1995). Due to the laborious and inaccurate quantitation using this technique, chromatographic techniques have been developed for analysis of caseins (Andrews et al, 1985; Christensen et al, 1989; Hollar et al, 1991; Strange et al, 1991; Syväoja, 1992; Calvo et al, 1992; NgKwai Hang and Chin, 1994). Although some of these can separate the major caseins in a whole casein fraction (Hollar et al, 1991), in most chromatograms $\alpha_{s 1}$-casein and $\alpha_{\mathrm{s} 2}$-casein are not baseline-separated, and the picture can be complicated when casein fractions from cheeses are run (Christensen et al, 1989; Exterkate and Alting, 1995).

Capillary electrophoresis (CE), a technique successfully used for analysis of a range of proteins (Grossman et al, 1989; Lindner et al, 1993; Werner et al, 1993; Otte et al, 1994), is an alternative to traditional slab gel electrophoresis and is complementary to liquid chromatography. In CE, separation is based on charge to mass ratio differences of the components as in gel

Table I. Major casein hydrolysis products found in cheese (Fox et al, 1993).

Principaux produits d'hydrolyse de la caséine retrouvés dans le fromage.

\begin{tabular}{lrl}
\hline Casein & Fragment & Trivial name \\
\hline$\kappa$-Casein (chymosin) & $1 \rightarrow 105$ & para- $\kappa$-casein \\
$\alpha_{\mathrm{s} 1}$-Casein (chymosin) & $24 / 25 \rightarrow 199$ & $\alpha_{\mathrm{s} 1}$-Casein-I \\
$\beta$-Casein (plasmin) & $29 \rightarrow 209$ & $\gamma_{1}$-Casein \\
& $106 \rightarrow 209$ & $\gamma_{2}$-Casein \\
$\gamma_{3}$-Casein
\end{tabular}


electrophoresis, but separation and quantification can be performed in one step as in high-pressure liquid chromatography (HPLC). Furthermore, the resolution potential of CE is higher than for HPLC (Grossman et al, 1989), only small volumes of buffer and sample are needed, generally non-toxic buffers are used, and capillaries used for CE are much cheaper than HPLC columns.

A few studies concerning $\mathrm{CE}$ analysis of caseins have been performed (Chen and Zhang 1992; de Jong et al, 1993; Kanning et al, 1993; Kristiansen et al, 1994). Kristiansen et al (1994) have shown that the four major caseins occurring in acid casein were separated at neutral $\mathrm{pH}$ in an untreated capillary. The separation could be improved by increasing the $\mathrm{pH}$ and using a buffer modifier and a coated capillary, and casein separation patterns resembling urea-PAGE patterns were obtained (unpubl results). However, the whey proteins were not separated from the caseins, which can present a problem if cheeses containing denatured whey proteins are analysed, or if the caseins are not isoelectrically separated from any native whey proteins present before analysis. De Jong et al (1993) have shown that a good analytical separation of all major milk proteins can be obtained by $\mathrm{CE}$ at low $\mathrm{pH}$ in coated capillaries using a polymeric buffer additive. The migration behaviour of the most phosphorylated forms of the $\alpha_{s 1}$ and $\alpha_{\mathrm{s} 2}$-caseins, however, was not investigated. Furthermore, no information on the migration of the major casein fragments produced during manufacture and ripening of cheeses is available.

The purpose of the present study was to apply the method of de Jong et al (1993) with slight modifications for analysis of caseins from cheese, and to identify the major caseins and primary casein hydrolysis products in cheese, and discuss the suitability of the method for determination of casein proteolysis occurring in cheeses.

\section{MATERIALS AND METHODS}

\section{Materials}

Trisodium citrate dihydrate, ammonium acetate, sodium dihydrogen phosphate monohydrate and urea were of analytical grade and obtained from Merck (Merck-Darmstadt, Germany). Hydroxypropyl methyl cellulose (HPMC, no 20.032-8, $2 \%$ solution $=4000 \mathrm{cps})$ was from AldrichChimie (Steinheim, Germany). All solutions were based on highly purified water (Milli-Q Plus, Millipore Corp, Bedford, MA, USA).

Fresh milk from two cows, one homozygotic for $\alpha_{\mathrm{s} 1}$-casein $\mathrm{B}, \beta$-casein $\mathrm{A} 1$ and $\kappa$-casein $\mathrm{A}$, the other homozygotic for $\alpha_{\mathrm{s} 1}$-casein $\mathrm{B}, \beta$-casein $A 2$ and $\kappa$-casein $B$, was obtained from the National Institute of Animal Science (Research Centre Foulum, Denmark). Acid casein was prepared from the milk as described by Kristiansen et al (1994). Fractions of pure $\alpha_{s_{1}}$-casein and $\beta$-casein were obtained by ion exchange of the acid casein containing $\beta$-casein $\mathrm{Al}$ (Kristiansen et al, 1994). Pure casein standards of $\alpha_{52}, \beta$ - and $\kappa$-casein, isolated as described by Rasmussen et al (1992a), were obtained from the Protein Chemistry Laboratory (University of Aarhus, Denmark). Other samples of $\beta$-casein (C-6905) and $\kappa$-casein (C-0406) as well as the tripeptide LysTyr-Lys (L-3271) were obtained from Sigma Chemical Co (St Louis, MO, USA). Rennet whey was prepared from fresh bulk milk as described by Otte et al (1994). Caseinomacropeptide was a gift from MD Foods Ingredients (Videbaek, Denmark).

Bovine chymosin (Chymogen, type B, 44 $\mathrm{CHU} / \mathrm{mL}$ ) was from Christian Hansen A/S (Hørsholm, Denmark). Bovine plasmin (no 602370 , $5 \mathrm{U} / \mathrm{mL}$ ) was from Boehringer-Mannheim $\mathrm{GmbH}$ (Mannheim, Germany).

Mozzarella (one to five weeks old) and Feta (six and 40 weeks old) cheeses were manufactured from ultrafiltered (UF) bovine milk for other projects at the department. The Danbo cheese ( 12 weeks old) was supplied by $\mathrm{Chr}$ Hansen $\mathrm{A} / \mathrm{S}$.

\section{Extraction of cheese}

Ten $\mathrm{g}$ of grated cheese was dissolved in $40 \mathrm{~mL}$ $0.5 \mathrm{~mol} / \mathrm{L}$ sodium citrate buffer, $\mathrm{pH} 8.5$, at $40^{\circ} \mathrm{C}$ with magnetic stirring for $\sim 1 \mathrm{~h}$. The volume was 
made up to $200 \mathrm{~mL}$ with distilled water, and the suspension was centrifuged $\left(4^{\circ} \mathrm{C}, 20 \mathrm{~min}\right.$, $2500 \mathrm{~g}$ ) and/or filtered through glass wool. The $\mathrm{pH}$ of the supernatant was lowered to 4.6 with $1 \mathrm{~mol} / \mathrm{L} \mathrm{HCl}$, and after centrifugation the supernatant was discarded and the precipitate allowed to drain. The drained precipitate was dissolved in sample buffer (see below). In a few instances the filtered citrate suspension of caseins was simply diluted with an equal volume of sample buffer.

\section{Hydrolysis of $\alpha_{\mathrm{s}}$-and $\kappa$-casein with chymosin}

$\alpha_{\mathrm{s}}$-Casein and $\kappa$-casein were dissolved at $10 \mathrm{mg} / \mathrm{mL}$ in $0.075 \mathrm{~mol} / \mathrm{L}$ ammonium acetate buffer, $\mathrm{pH} 6.2$, and hydrolysed with 0.3 and $0.003 \%$ chymosin respectively, as described by Kristiansen et al (1994). Samples $(100 \mu \mathrm{L})$ withdrawn at different intervals after enzyme addition $\left(\alpha_{\mathrm{c}}\right.$-casein: $t=0,1 / 2,1,2$ and $4 \mathrm{~h} ; \kappa$-casein: $t=$ $0,5,10,20$ and $50 \mathrm{~min}$ ) were immediately boiled for $5 \mathrm{~min}$ and cooled to room temperature. The $\mathrm{pH}$ was lowered to 4.6 , and after equilibration for $20 \mathrm{~min}$, the precipitates were collected by centrifugation $(11000 \mathrm{~g}, 5 \mathrm{~min})$.

\section{Hydrolysis of $\beta$-casein with plasmin}

Two samples of $\beta$-casein $(10 \mathrm{mg} / \mathrm{mL})$, one containing only $\beta$-casein $A 1$ and one containing a mixture of genetic variants (from Sigma), were hydrolysed with plasmin $(10 \mu \mathrm{L} / 850 \mu \mathrm{L}$ of sample) in $0.05 \mathrm{~mol} / \mathrm{L}$ phosphate buffer, $\mathrm{pH} 7.0$, at $37^{\circ} \mathrm{C}$. The caseins in the $100-\mu \mathrm{L}$ samples withdrawn after 1,2,3,4 and $23 \mathrm{~h}$ of incubation with plasmin were precipitated at $\mathrm{pH} 4.6$, centrifuged, and evaporated to dryness (Hetovac VR-1, Heto Lab Equipment A/S, Allerød, Denmark).

\section{Sample pretreatment}

To dissociate the caseins and insoluble hydrolysis products, all samples were dissolved in a sample buffer containing $8 \mathrm{~mol} / \mathrm{L}$ urea and $10 \mathrm{mmol} / \mathrm{L}$ dithioerythritol (DTE) at $\mathrm{pH} 8$, and left for at least $1 \mathrm{~h}$ at room temperature before filtration ( $0.45 \mu \mathrm{m}$ Minisart, Sartorius) and $\mathrm{CE}$ analysis. The isoelectrically precipitated casein was dissolved at $30 \mathrm{mg} / \mathrm{mL}$ and the purified casein standards at $10 \mathrm{mg} / \mathrm{mL}$. Casein precipitate from $100 \mu \mathrm{L}$ hydrolysate was dissolved in $80 \mu \mathrm{L}$ sample buffer $(\sim 13 \mathrm{mg} / \mathrm{mL})$ and casein precipitate corresponding to approximately $0.1 \mathrm{~g}$ (Feta) or $1 \mathrm{~g}$ of cheese (UF-Mozzarella and Danbo) was dissolved in $2 \mathrm{~mL}$ sample buffer; the samples from UF-Mozzarella and Danbo cheeses were further diluted two and three times respectively with sample buffer before analysis. To most samples, additionally $1 \mu \mathrm{L}$ of the tripeptide Lys-Tyr-Lys $(50 \mathrm{mg} / \mathrm{mL})$ was added per $50 \mu \mathrm{L}$ of sample as a reference compound.

\section{Capillary electrophoresis}

Analysis was performed on a Waters Quanta 4000 Capillary Electrophoresis System, with $50 \mu \mathrm{m}$-id capillaries, either hydrophilically coated (CElect ${ }^{\mathrm{TM}}-\mathrm{P} 150$, Supelco, Inc, Bellafonte, PA, USA) or untreated (J\&W Scientific, Folsom, CA, USA). Unless otherwise stated, the total length of the coated capillary was $43 \mathrm{~cm}$ and the untreated capillary $60 \mathrm{~cm}$. The sample was injected hydrodynamically at the cathodic end for $15-30 \mathrm{~s}$. The run buffer was $10 \mathrm{mmol} / \mathrm{L}$ sodium phosphate with $6 \mathrm{~mol} / \mathrm{L}$ urea, $\mathrm{pH} 2.5$, made up as described by de Jong et al (1993), but with $0.05 \%$ (or $0.02 \%)(w / v)$ hydroxypropyl methyl cellulose (HPMC) instead of methylhydroxyethylcellulose (MHEC). Separation was performed at constant voltage, resulting in a current of approximately $40 \mu \mathrm{A}$. The components were detected on column $7.5 \mathrm{~cm}$ from the anode by their UV absorbance at $214 \mathrm{~nm}$. Millennium ${ }^{\mathrm{TM}} 2010$ Chromatography Manager version 2.1 (Waters Chromatography Div, Milford, MA, USA) was used for data collection and processing. Between runs the capillary was purged for 3 or 7 min with run buffer. The first electrophoregram in a series was always discarded.

The linearity of the method in the untreated capillary was assessed with a sample from UF-Feta by varying the sample injection time from 5 to $40 \mathrm{~s}$, followed by variation from 40 to $5 \mathrm{~s}$. Peak areas were calculated as the average from the two determinations. Standard curves were made with varying concentrations ( 2 to $20 \mathrm{mg} / \mathrm{mL}$ sample buffer) of the purified

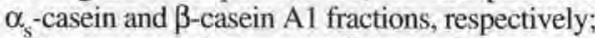
each concentration was analysed only once.

The repeatability using the untreated and the coated capillary respectively was assessed by nine consecutive injections of acid casein and 
caseins from UF-Feta cheese, respectively. All injections in one series were performed without exchange of buffer.

\section{RESULTS AND DISCUSSION}

\section{Separation of caseins}

By use of HPMC in the CE run buffer, the casein separation pattern obtained with the hydrophilically coated capillary (fig 1 , top) was very similar to that obtained when MHEC was used (de Jong et al, 1993). Comparison with the results of de Jong et al (1993) suggests that the peak migrating at $20 \mathrm{~min}$ in figure 1 is $\alpha_{\mathrm{s} 2}$-casein and that the peaks migrating at $\sim 22 \mathrm{~min}$ and $\sim 25 \mathrm{~min}$ are $\alpha_{\mathrm{s1}}$ - and $\beta$-casein, respectively. The peak at $\sim 24.5 \mathrm{~min}$ similarly should be $\kappa$-casein. These designations were confirmed by analysis of individual casein standards, as shown in the lower part of figure 1 .

Despite minor day-to-day variations in migration times $\left(t_{\mathrm{m}}\right)$, the peaks for the caseins in the standards can be easily recognized in the electrophoregram of the acid casein (fig 1). It can be seen that $\alpha_{\mathrm{s} 2}$-casein is separated into at least four peaks migrating between 19 and $21 \mathrm{~min}$, which is consistent with the existence of four phosphorylation states of this protein containing ten to 13 phosphate groups (Swaisgood, 1992). The additional peaks might stem from disulphide-linked dimers from variants with different numbers of phosphate groups (Hoagland et al, 1971; Rasmussen et al, $1992 \mathrm{~b}$ ), as these dimers are only partly reduced by addition of DTE (Rasmussen and Petersen, 1991).

Apart from $\alpha_{\mathrm{s} 1}$-casein $\left(t_{\mathrm{m}} \sim 21.5 \mathrm{~min}\right)$, the sample used as standard for $\alpha_{\mathrm{s} 1}$-casein apparently also contained $\alpha_{\mathrm{s} 2}$-casein and a few other components. The distance between the $\alpha_{\mathrm{s} 1}$-casein peak and the following peak $\left(t_{\mathrm{m}} \sim 23 \mathrm{~min}\right)$ is similar to the distance between the two highest $\alpha_{\mathrm{s} 2}$-casein peaks, that differ by only one phosphate

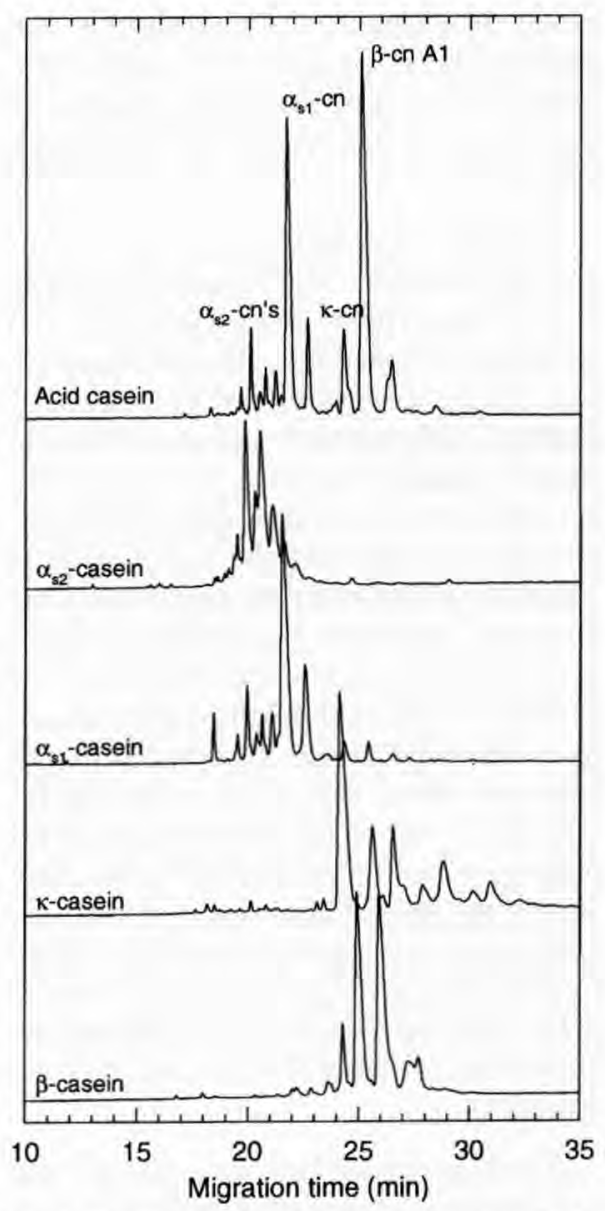

Fig 1. Capillary electrophoretic separation of the caseins in acid casein containing $\beta$-casein ( $\beta$-cn) A1 (upper electropherogram) and identification of major caseins by analysis of casein standards. The scale of the acid casein is enlarged by a factor of 1.7 in comparison to the standards. Separation was performed in a coated capillary at 14 $\mathrm{kV}(\sim 40 \mu \mathrm{A})$. Other conditions are described in the Methods section.

Séparation par électrophorèse capillaire des caséines d'un précipité acide de caséine contenant la caséine $\beta$ ( $\beta$-cn) Al (électrophérogramme en haut) et identification des caséines principales par analyse des standards. L'échelle de la caséine acide est aggrandie d'un facteur de 1,7 par rapport aux standards. La séparation est réalisée avec un capillaire traité à $14 \mathrm{kV}$ $(\sim 40 \mu \mathrm{A})$. Les autres conditions sont décrites dans la section 'Méthodes'. 
group. The peak at $\sim 23 \mathrm{~min}$, thus, is supposed to be $\alpha_{\mathrm{s} 0}$-casein $\left(\alpha_{\mathrm{s} 1}\right.$-casein 9P), which contains one phosphate group more than $\alpha_{\mathrm{s} 1}$-casein $\left(\alpha_{\mathrm{s} 1}\right.$-casein 8P; Swaisgood, 1992).

$\kappa$-Casein separated into a range of components of which $\sim 50 \%$ migrated as a peak at $\sim 24.5 \mathrm{~min}$ (fig 1). $\kappa$-Casein is prepared from bulk milk and thus should contain the two genetic variants, $\mathrm{A}$ and $\mathrm{B}$, in approximately equal amounts (Swaisgood, 1992). In figure 1 , however, only one dominating peak is visible, which is in accordance with complete protonisation at $\mathrm{pH} 2.5$ of Asp 148 in variant $\mathrm{A}$, and thus similar net charge as the B variant (Ala 148). The following peaks are not supposed to be multimers of $\kappa$-casein, as these should be fully reduced by $9 \mathrm{mmol} / \mathrm{L}$ DTE (Rasmussen and Petersen, 1991). They might represent glycoforms of $\kappa$-casein containing $N$-acetyl neuraminic acid, as Otte et al (1995) have shown, that the $\mathrm{C}$-terminal part of $\kappa$-casein, containing this negatively charged carbohydrate, has a longer migration time at pH 2.5 than the C-terminal part without carbohydrates or with neutral carbohydrate moieties.

The $\beta$-casein standard (fig 1 , bottom) also was prepared from bulk milk and thus should contain several genetic variants dominated by $\mathrm{A} 1$ and $\mathrm{A} 2$. Accordingly, the migration of the first major $\beta$-casein peak at 25 min coincides with the $\beta$-casein peak in acid casein containing only $\beta$-casein A1 (fig 1, top). Confirmation of the $\beta$-caseins being $\mathrm{Al}$ and $\mathrm{A} 2$, respectively (in that order) is given below (fig 2). From their primary structure, the minor $\beta$-casein genetic variants $\mathrm{B}$ and $\mathrm{C}$ are expected to migrate ahead of the $\mathrm{A} 1$ variant, and $\mathrm{A} 3$ to migrate behind the $A 2$ variant, respectively. It is thus possible that two of the minor peaks in front of $\beta$-casein A1 represent the B and C variants of $\beta$-casein, and that one of the components migrating behind $\beta$-casein $\mathrm{A} 2$ represents the $\mathrm{A} 3$ variant. These minor peaks were not identified.

Figure 2 shows that the predominant $\beta$-casein variants, $\mathrm{A} 1$ and $A 2$, are well separated by the method used, and that A 1 migrates ahead of A2. The A1 variant of $\beta$-casein contains His (instead of Pro) at position 67 , which is positively charged below $\mathrm{pH} 6$ and results in a higher mobility

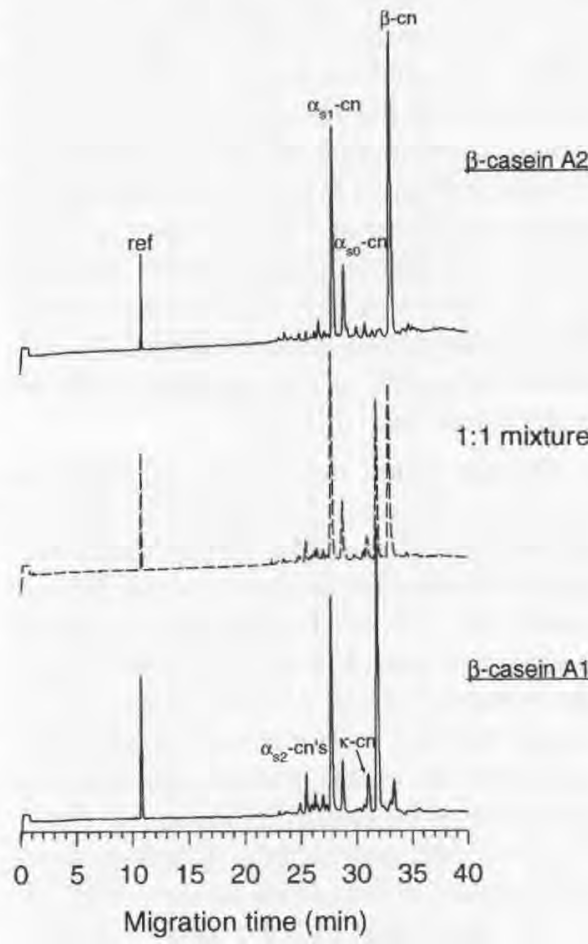

Fig 2. Capillary electropherograms of acid casein containing only $\beta$-casein $A 1$ and $\beta$-casein $A 2$ respectively, and of a 1:1 mixture of the two samples (dashed line). Separations were performed in a $58.5-\mathrm{cm}$ long coated capillary, at $20 \mathrm{kV}$ $(\sim 65 \mu \mathrm{A})$; ref: reference compound (Lys-TyrLys).

Électrophérogrammes capillaires des précipités acides de caséine contenant les caséines $\beta$ AI ou A2 seulement, et d'un mélange des deux échantillons (ligne pointillée). La séparation est réalisée avec un capillaire traité de $58,5 \mathrm{~cm}$ à $20 \mathrm{kV}(\sim 65 \mu \mathrm{A})$; ref : composé de référence (Lys-Tyr-Lys). 
at low $\mathrm{pH}$. This is in contrast to the analysis at high $\mathrm{pH}$, where the two $\beta$-casein variants have the same net charge and migrate as a single zone (Kristiansen et al, 1994).

\section{Application to caseins from cheeses}

\section{Isoelectrically precipitated caseins}

When applied to caseins from cheeses, different profiles were obtained from UF-Feta and Danbo (fig 3). The casein pattern of the UF-Feta cheese (fig 3, left) looked very much like that for acid casein (fig 1), as only limited proteolysis occurred during manufacture and storage of this cheese, and the peaks for the $\alpha_{\mathrm{s1}}{ }^{-}, \alpha_{\mathrm{s} 0^{-}}$and $\beta$-caseins were immediately recognisable. The UF-Feta cheese was manufactured from bulk milk; accordingly, distinct peaks for the two dominating $\beta$-casein variants $\mathrm{A} 1$ and $\mathrm{A} 2$ were visible. The peak just before $\beta$-casein A1 contained $\kappa$-casein, as shown by analysis of the Feta sample spiked with $\kappa$-casein (not shown).

The electrophoregram of the caseins from the Danbo cheese (fig 3, right) was somewhat more complicated due to the presence of a number of hydrolysis products. Comparison with the analysis of pure $\beta$-casein showed that the peaks at $\sim 25$ and $\sim 26 \mathrm{~min}$ were due to $\beta$-casein $\mathrm{A} 1$ and $\mathrm{A} 2$, respectively. Other major intact caseins were not positively demonstrated. The casein degradation products most often found in various cheeses stem from the chymosin-catalysed hydrolysis of $\kappa$ - and $\alpha_{\mathrm{s1}}$-casein and from the plasmin catalysed-hydrolysis of

\section{FETA}

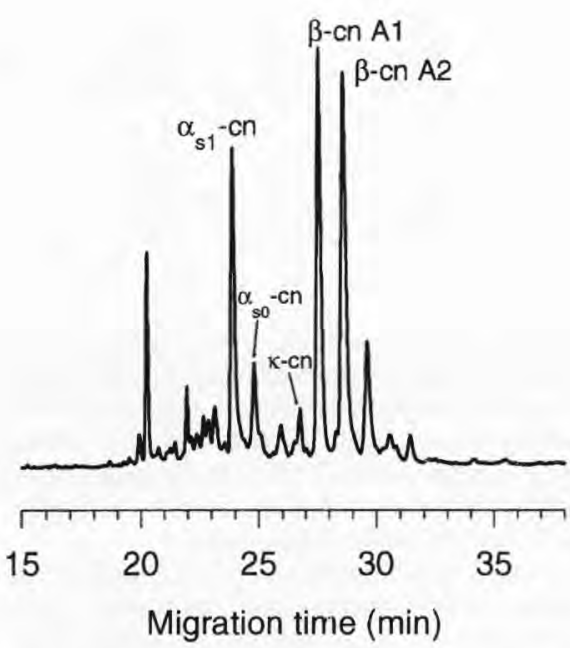

\section{DANBO}

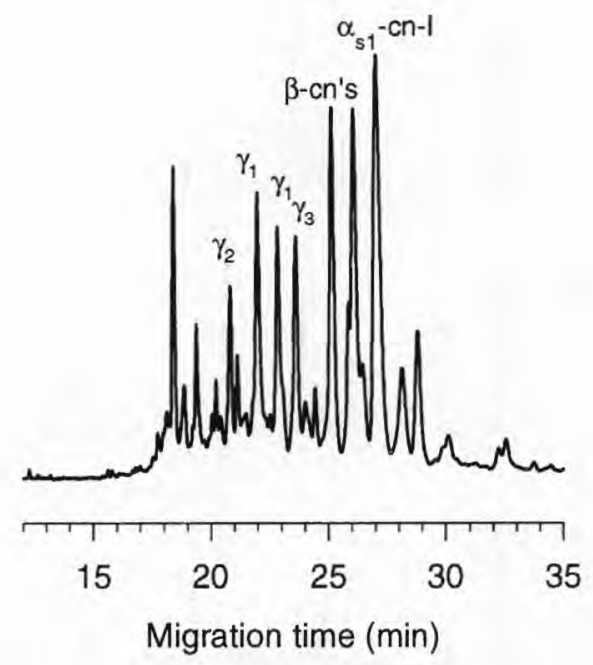

Fig 3. Capillary electrophoresis of caseins from UF-Feta (6 weeks old) and Danbo (12 weeks old) cheeses. Capillary electrophoresis conditions as described in the legend for figure 1 . Électrophorèse capillaire des caséines d'un Feta-UF (âgé de 6 semaines) et d'un Danbo (âgé de 12 semaines). Les conditions d'électrophorèse sont les mêmes que celles décrites sous la figure 1. 
$\beta$-casein (table I) (Christensen et al, 1989; Creamer, 1991; Calvo et al, 1992; Centeno et al, 1994). In order to identify these major degradation products, hydrolysis of individual caseins with the relevant enzymes was performed (fig 4).

$\alpha_{s 1}$-Casein with added chymosin, both in solution and in cheese, is rapidly hydrolysed at the carboxylic side of Phe 23 or Phe24 to give the soluble peptide f1-23/24 and the $\mathrm{pH} 4.6$ insoluble peptide, f25-199,

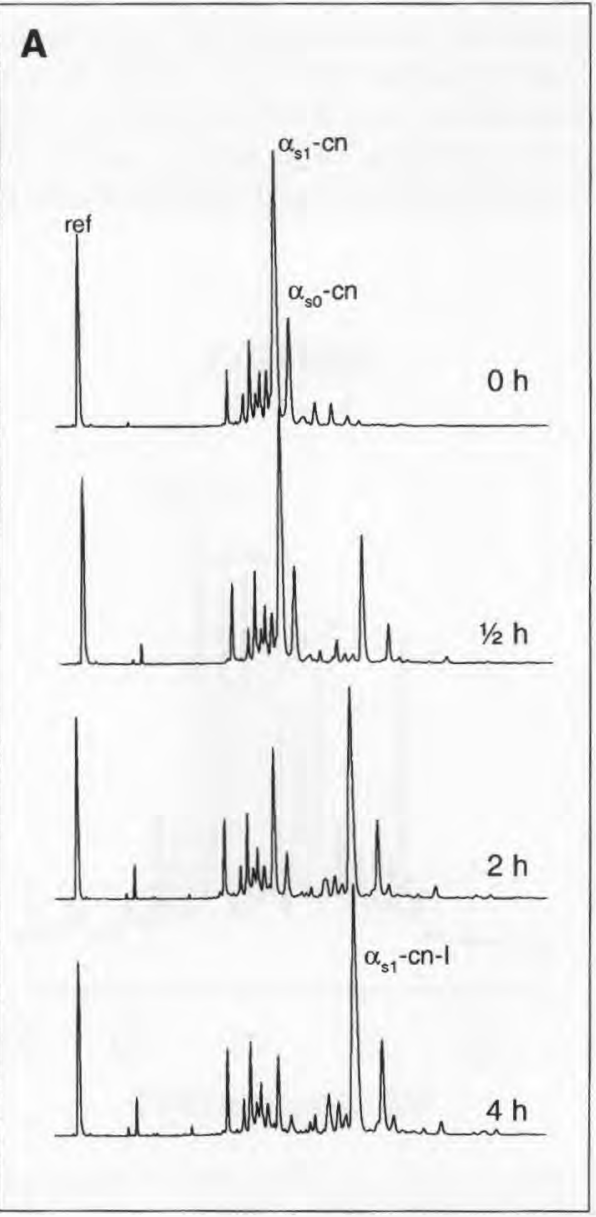

named $\alpha_{s 1}$-casein-I (Mulvihill and Fox, 1979; Grappin et al, 1985; Kristiansen et al, 1994). Accordingly, Figure 4A shows that the peak for $\alpha_{\mathrm{s1}}$-casein (and for $\alpha_{\mathrm{s} 0}$-casein) disappeared upon the action of chymosin on $\alpha_{\mathrm{s}}$-casein in solution, resulting in appearance of a new peak with higher $t_{\mathrm{m}}$ in the electropherograms (and a minor peak with even higher $t_{\mathrm{m}}$ ). These new peaks are believed to represent the $\mathrm{C}$-terminal fragment (f25-199) of $\alpha_{\mathrm{s} 1}$-casein and $\alpha_{\mathrm{s} 0}$-casein, respectively. The migration time of the peak

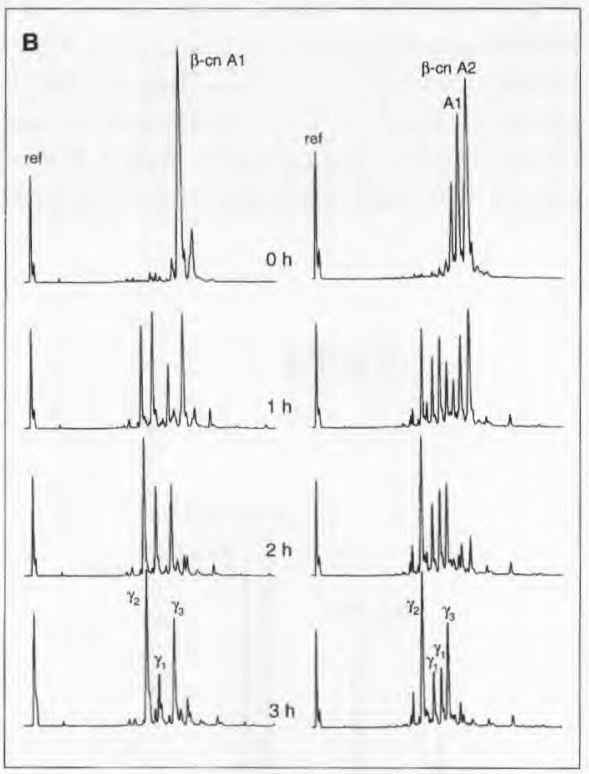

Fig 4. Capillary electrophoresis of samples from isolated casein fractions taken at different intervals after addition of protease. A. $\alpha_{\mathrm{s}}$-Casein hydrolysed by chymosin. B. $\beta$-Casein Al (left) and $\beta$-casein variants from bulk milk (right) hydrolysed by plasmin. CE conditions as for figure 1; ref: reference compound.

Électrophorèse capillaire des échantillons de caséines isolées prélevés à différents temps après l'addition de la protéase. A. Caséine $\alpha_{s}$ hydrolysée par la chymosine. B. Caséine $\beta A 1$ (à gauche) et caséine $\beta$ du lait cru (à droite) hydrolysées par la plasmine. Conditions d'électrophorèse identiques à celles de la figure 1 ; ref: composé de référence. 
for $\alpha_{\mathrm{s} 1}$-casein-I, calculated relative to the reference compound (Lys-Tyr-Lys) and compared to the relative migration time of the $\beta$-caseins suggests that the $\alpha_{\mathrm{s} 1}$-casein-I has a lower mobility than $\beta$-casein $A 2$. Thus, the peak at $27 \mathrm{~min}$ in figure 3 should be $\alpha_{\text {s1 }}$-casein-I. This was further confirmed by analysis of a mixture of $\alpha_{\mathrm{s1}}$-casein hydrolysed for $4 \mathrm{~h}$ (mainly consisting of $\alpha_{\mathrm{s} 1}$-casein-I) and casein from Danbo cheese, as only one single peak appeared after the peak for $\beta$-casein A2. The small peak next to the $\beta$-casein A2 in the electrophoregram from the Feta cheese $\left(t_{\mathrm{m}} \sim 29.7 \mathrm{~min}\right.$; fig 3 , left) likewise represents $\alpha_{s 1}$-casein-I.

Figure 4B (left) shows that upon incubation with plasmin, the $\beta$-casein $A 1$ was quickly hydrolysed to yield three main components $(2 \mathrm{~h})$. According to Swaisgood (1992) these are the so-called $\gamma$-caseins (see table I). It seems that upon further incubation, the second of the $\gamma$-caseins was gradually transferred into the two other $\gamma$-caseins. This can be explained if the second $\gamma$-casein is $\gamma_{1}$-casein (f29-209). By splitting off the fragments f29-105 and f29-107 respectively from the $\gamma_{1}$-casein, the $\gamma$-caseins $\gamma_{2}$ and $\gamma_{3}$ result. $\gamma_{2}$-Casein contains His and Lys at positions 106 and 107, which are positively charged at low $\mathrm{pH}$, and thus has the highest mobility under the present conditions. Therefore, the order of migration times of the three $\gamma$-caseins must be $\gamma_{2}<\gamma_{1}<\gamma_{3}$.

When $\beta$-casein from bulk milk was used as a substrate for plasmin, four components resulted (fig $4 \mathrm{~B}$, right, $2 \mathrm{~h}$ ), of which the two with intermediate migration were further degraded during longer incubation with plas$\mathrm{min}$. As the difference in the primary sequences of $\beta$-casein $\mathrm{A} 1$ and $\mathrm{A} 2$ is in position 67 (His and Pro, respectively), a position only contained in $\gamma_{1}$-casein, the results are in agreement with formation of two different $\gamma_{1}$-caseins, one from each of the $\beta$-caseins A1 and A2, but only one $\gamma_{2}$-and one $\gamma_{3}$-casein.
The Danbo cheese (fig 3, right) contains both the $\mathrm{A} 1$ and the $\mathrm{A} 2$ variants of $\beta$-casein, and thus four $\gamma$-caseins should result from their partial degradation. By comparison of relative migration times of the peaks in the electropherograms from the Danbo cheese and the $\gamma$-casein hydrolysates, the $\beta$-caseins were identified as shown in figure 3 .

Analysis of $\alpha_{51}$-casein mixed with $\gamma$-caseins from $\beta$-casein Al showed that $\alpha_{s 1}$-casein and $\gamma_{1}$-casein Al were co-migrating (results not shown). However, a slight increase in $\mathrm{pH}$ and buffer concentration changed the relative mobility of the $\alpha_{\mathrm{sl}}$-casein and the $\gamma$-caseins (not shown). Thus, due to the high efficiency of CE, it should be possible to obtain a separation of all five components by slight modification of the $\mathrm{pH}$. Otherwise the degradation of $\alpha_{\mathrm{sl}}$-casein can be deduced from the appearance of $\alpha_{\mathrm{s} 1}$-casein-I.

\section{Use of untreated capillary}

All results reported till now were obtained using the CElect P1 coated capillary according to de Jong et al (1993). When many cheese samples were run in series, sometimes splitting of all peaks occurred (results not shown), a phenomenon that could not be avoided unless the capillary was replaced by a new one. As untreated capillaries are much cheaper than the coated capillaries, it was preferable to use the untreated capillaries. At $\mathrm{pH} 2.5$, the silanol groups of the untreated capillary should be protonated, preventing the positively charged caseins from interfering with the capillary wall. We expected therefore that the separation would not be significantly deteriorated by changing to an untreated capillary. A comparison of electropherograms of selected samples run in the coated and the untreated capillary, respectively, is shown in figure 5 .

In fact, very similar casein patterns were obtained when caseins from Mozzarella cheeses were analysed using the CElect P1 
and the untreated capillary (fig 5). This was also the case when a sample of acid casein was analysed (results not shown). A higher absolute absorbance was obtained with the coated capillary, otherwise the relative height of the peaks for the major caseins seemed to be identical with the two capillaries (compare fig $5 \mathrm{~A} / \mathrm{B}$ and $\mathrm{C} / \mathrm{D}$, respec-

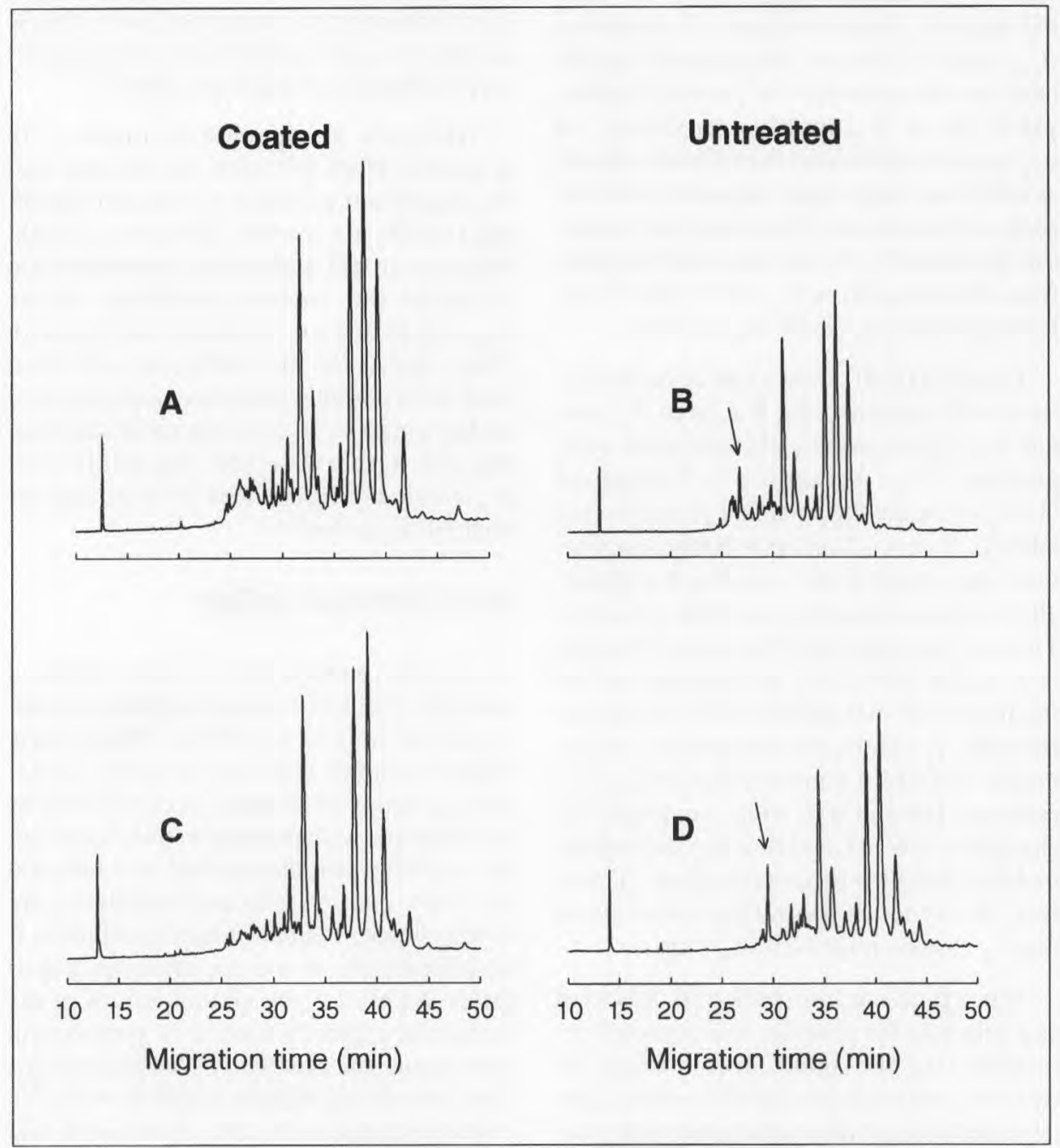

Fig 5. Capillary electrophoresis of caseins from Mozzarella cheeses using a hydrophilically coated capillary (A and $\mathbf{C})$ and an untreated capillary $(\mathbf{B}$ and $\mathbf{D})$, respectively. A, B: 1 week old; $\mathbf{C}, \mathbf{D}: 5$ weeks old. Capillary electrophoresis conditions, coated capillary: $52 \mathrm{~cm}, 13.5 \mathrm{kV}(\sim 36 \mu \mathrm{A}), 0.02 \%$ HPMC; untreated capillary: $60 \mathrm{~cm}, 17 \mathrm{kV}(\sim 36 \mu \mathrm{A}), 0.02 \%$ HPMC. Arrows indicate para- $\kappa$-casein. Électrophorèse capillaire des caséines des fromages de Mozzarella avec un capillaire traité $(\boldsymbol{A}$ et $\boldsymbol{C})$ et un capillaire non traité $(\boldsymbol{B}$ et $\boldsymbol{D})$, respectivement. $\boldsymbol{A}, \boldsymbol{B}:$ Mozzarella âgée d'une semaine $; \boldsymbol{C}, \boldsymbol{D}$ : âgée de 5 semaines. Conditions d'électrophorèse capillaire traité : $52 \mathrm{~cm}, 13,5 \mathrm{kV}(\sim 36 \mu \mathrm{A}), 0,02 \%$ HPMC, capillaire non traité : $60 \mathrm{~cm}, 17 \mathrm{kV}(\sim 36 \mu \mathrm{A}), 0,02 \% \mathrm{HPMC}$. Les flèches indiquent la caséine para- $\kappa$. 
tively). The identification of major caseins and degradation products presented above for the coated capillary, therefore is considered to be valid for the untreated capillary also, the four highest peaks representing $\alpha_{\mathrm{s} 1}$-casein, $\beta$-casein A1, $\beta$-casein A2 and $\alpha_{\mathrm{s} 1^{-}}$-casein-I, respectively. The only clearly visible difference between electrophoregrams obtained with the two capillaries was that a peak appeared in the first part of the electrophoregrams with the untreated capillary, but not with the coated capillary (arrows in fig 5). This peak, however, had a much higher electrophoretic mobility than the $\alpha_{\mathrm{s} 1}$-casein, which is the first migrating major casein, and also higher than the $\gamma$-caseins, and thus should not interfere with the determination of the major caseins and their degradation products. By mixing the Mozzarella sample with a sample of chymosin-treated $\kappa$-casein, this peak was shown to represent para- $\mathrm{K}$-casein (table I). The narrow peaks at $\sim 20 \mathrm{~min}$ in the electrophoregrams from the Feta and at $\sim 18 \mathrm{~min}$ in the electrophoregrams from the Danbo cheese (fig 3) very likely also represent para- $\mathrm{K}$ casein. The latter results, however, were obtained with the coated capillary, indicating that the absence of para-K-casein in the Mozzarella cheeses analysed with the coated capillary (fig 5) is not due to this $\mathrm{K}$-casein fragment interacting with the hydrophilic groups of the coated capillary. The casein profiles of Mozzarella cheeses using the coated capillary were obtained shortly after addition of sample buffer, whereas the analyses using the untreated capillary were performed at a later date, suggesting that para$\kappa$-casein was only slowly liberated by disulfide reduction, resulting in increased concentration with increasing time after addition of sample buffer (compare the section on varying sample preparation procedure below).

An example of application of the casein analysis method with an untreated capillary to follow the casein degradation during limited cheese maturation is shown in figure 6 . Although the proteolysis rate of Mozzarella

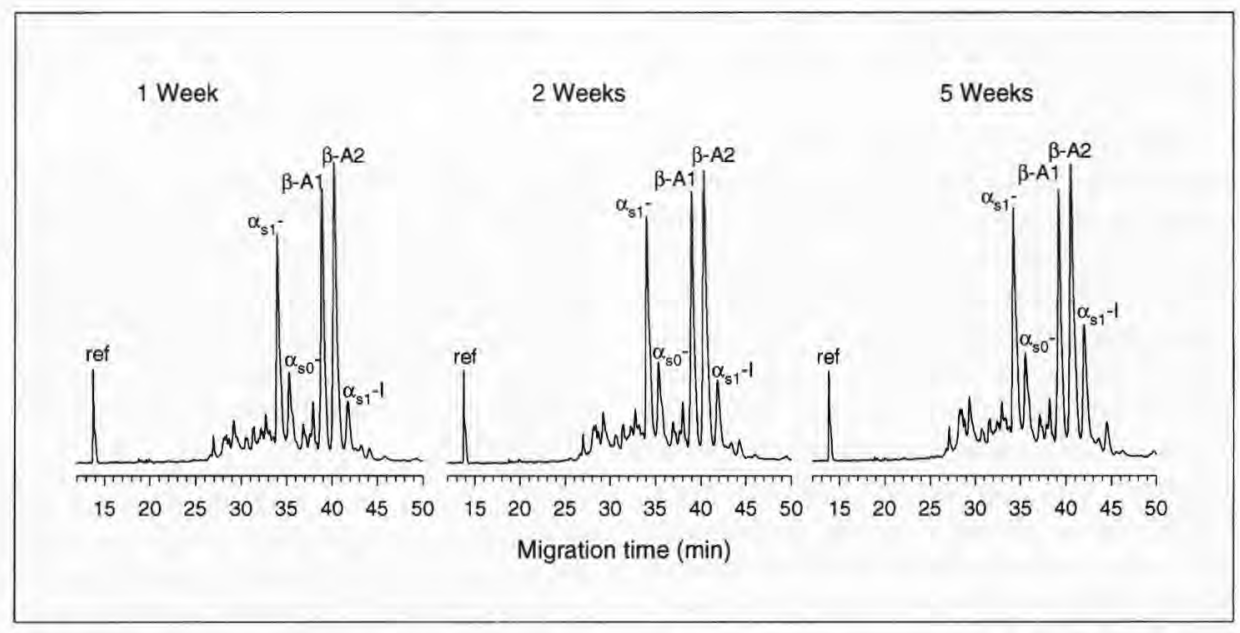

Fig 6. Capillary electrophoresis of caseins from UF-Mozzarella cheeses stored at $5{ }^{\circ} \mathrm{C}$ for 1 to 5 weeks. Untreated capillary, $17 \mathrm{kV}(\sim 35 \mu \mathrm{A})$; ref: reference compound.

Électrophorèse capillaire des caséines de Mozzarella-UF conservée à $5^{\circ} \mathrm{C}$ pendant $I$ à 5 semaines. Capillaire non traité, $17 \mathrm{kV}(\sim 35 \mu \mathrm{A})$; ref: composé de référence. 
cheese is very low and the present cheeses were made with the inclusion of whey proteins which generally retard the maturation process, a noticeable increase in the concentration of the $\alpha_{\mathrm{s} 1}$-casein-I was seen during the few weeks of storage at $5^{\circ} \mathrm{C}$ (fig 6). Surprisingly, the peak for $\alpha_{\mathrm{sI}}$-casein did not decrease accordingly, perhaps because a small fraction of the $\beta$-casein had been transformed into $\gamma_{1}$-casein, which has a mobility similar to $\alpha_{\mathrm{s} 1}$-casein under the present conditions.

Probably much more dramatic changes in the casein pattern would be revealed if analysis were performed on cheeses that require maturation, eg, Danbo or Gouda, as has been shown previously by use of urea-PAGE (Visser and de Groot-Mostert, 1977).

\section{Varying sample preparation procedure}

The cheese samples treated above were all prepared by acid precipitation of the caseins from a citrate suspension of the cheese. In order to examine whether the sample preparation procedure could be simplified by omission of the precipitation step, analysis of variously treated citrate suspensions of UF-Feta was performed.

When the citrate solution of the UF-Feta cheese was analysed without addition of sample buffer, peaks for the major caseins were recognisable in the electrophoregram, but they were broad and insufficiently separated and had a low number of theoretical plates (results not shown). Dilution of the sample with water $(1: 1)$ only gave a limited improvement. However, when the citrate solution was diluted $(1: 1)$ with sample buffer, the caseins and hydrolysis products were very well separated with similar or higher efficiency than the acid-precipitated caseins (fig 7).

It can be seen from figure 7 that the separation of the caseins in the acid-precipitated sample and in the citrate suspension
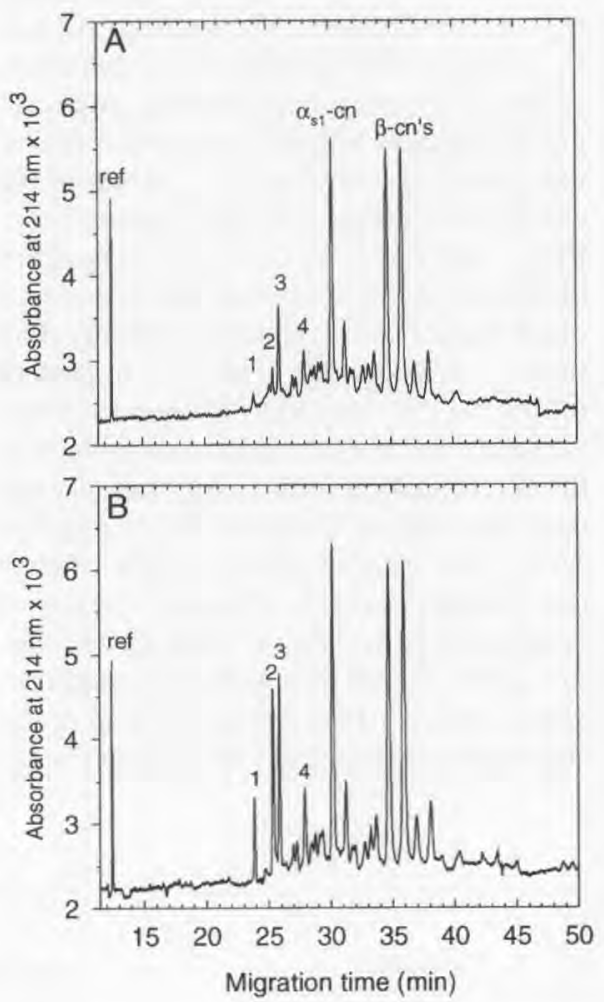

Fig 7. Capillary electrophoresis of caseins from UF-Feta cheese stored at $5{ }^{\circ} \mathrm{C}$ for 40 weeks. A. $\mathrm{pH} 4.6$ precipitate of citrate solution with added sample buffer ( $2 \mathrm{~mL} / \mathrm{mL}$ citrate solution). B. Citrate solution diluted 1:1 with sample buffer. Untreated capillary, $17 \mathrm{kV}(\sim 40 \mu \mathrm{A})$; ref: reference compound. Peak identification: $1, \alpha$-lactalbumin; 2, $\beta$-lactoglobulin; 3 , para- $\kappa$-casein; $4, \alpha_{\mathrm{s} 2}$-casein.

Electrophorèse capillaire des caséines d'un Feta$U F$ conservé à $5{ }^{\circ} \mathrm{C}$ pendant 40 semaines. A. Précipité à $\mathrm{pH} 4,6$ de la solution de citrate, avec le tampon pour échantillon ajouté $(2 \mathrm{~mL} / \mathrm{mL}$ solution citrate). B. Solution de citrate dilué $1: 1$ avec le tampon pour échantillon. Capillaire non traité, $17 \mathrm{kV}(\sim 40 \mu \mathrm{A})$ : ref : composé de référence. Identification de pic : $1, \alpha$-lactalbumine ; $2, \beta$-lactoglobuline ; 3 , caséine para- $\kappa$ : 4 , caséine $\alpha_{s 2}$. 
diluted with sample buffer was almost identical, and the peak widths were very similar. The slightly depressed peak heights of the caseins in the acid-precipitated sample (fig 7A) in comparison with the unprecipitated sample (fig 7B) might be due to inaccuracies in pipetting small volumes. One noticeable difference between the electropherograms shown in figure 7 , however, was the occurrence of four narrow but significant peaks in the first part of the electropherogram from the unprecipitated sample (fig 7B), components with higher mobility than the caseins. However, these peaks, designated 1 to 4 , can also be distinguished in the electropherogram from the acid-precipitated sample (fig 7A), but at much lower intensity. They were not present in the electropherograms of citrate solutions without sample buffer, in which only one peak of the same height as peak 1 was seen but at a migration time of $20 \mathrm{~min}$ (results not shown). This suggests that the components 1 to 4 were associated with each other in the citrate solution, but became dissociated upon addition of urea and DTE. The low concentrations of these components in the $\mathrm{pH}$ 4.6-precipitated cheese sample can be explained if the associated molecules are partly soluble at $\mathrm{pH} 4.6$, or not fully dissociated upon addition of sample buffer. By mixing the unprecipitated cheese sample with relevant amounts of rennet whey and hydrolysed $\kappa$-casein respectively, the three first peaks were identified as $\alpha$-lactalbumin, $\beta$-lactoglobulin and para- $\kappa$-casein, respectively. Peak 4 has the same relative $t_{\mathrm{m}}$ as $\alpha_{s 2}$-casein. Due to their content of cysteic residues the $\beta$-lactoglobulin, $\alpha_{\mathrm{s} 2}$-casein and $\kappa$-casein/para- $\kappa$-casein are able to form disulfide bonded aggregates (Elfagm and Wheelock, 1978). $\alpha$-Lactalbumin also contains eight $C y s$ residues, but all are engaged in disulfide bridges. Probably $-\mathrm{SH} / \mathrm{S}-\mathrm{S}$ interchange reactions had occurred between the four proteins during the short heat-treatment of the milk before cheese formation.
These results indicate that the simpler sample preparation is a precondition for obtaining quantitative results on the para$\kappa$-casein, and suggests that trials with varying concentrations and varying times of incubation with urea and DTE should be performed in order to ensure that all aggregates are solubilised.

The complementary part of $\kappa$-casein formed by the chymosin catalysed cleavage of $\kappa$-casein, the caseinomacropeptide (f106-169; Otte et al, 1995) might also be present in some cheeses, eg, fully concentrated UF-cheeses. As this peptide is soluble at $\mathrm{pH} 4.6$, it is present in the unprecipitated samples of such cheeses. Analysis of a caseinomacropeptide sample in the untreated capillary, however, showed that this peptide has a very low mobility under the present conditions and was migrating far behind the $\alpha_{\mathrm{s} 1}$-casein-I. Thus, omission of the acid precipitation step in the sample preparation procedure should not result in the presence of any major compound that would interfere with the determination of the major caseins and hydrolysis products.

\section{Performance of the method}

The efficiency of the method was high, giving theoretical plate numbers for the major casein peaks in acid casein and acid precipitated cheese casein of 100 000-300 000 per metre, depending on the sample composition, dilution and the state of the capillary. The plate numbers obtained with the untreated capillary and the coated capillary for the individual caseins in the Mozarella samples (fig 5) were very similar, only slightly higher with the untreated capillary. The proteins in the rennet whey sample gave peak efficiencies exceeding 300000 theoretical plates $/ \mathrm{m}$. These values are a little lower than the efficiency obtainable by use of a citrate buffer as the CE electrolyte (de Jong et al, 1993), but still sufficient to give complete resolution of the caseins. 
The repeatability of the method in the coated and the untreated capillary was also very similar (table II). With both capillaries there was a good repeatability on the relative migration times, $\sim 0.5 \%$ relative standard deviation. However, the repeatability of the peak areas and normalised peak areas was not satisfactory. The relative standard deviations (RSD) of 6-8\% gave only a twofold improvement over the repeatability obtainable by scanning of electrophoresis gels (Madsen JS, pers commun). These high RSD values might be due to lack of temperature control and/or extensive capillary wash between runs, as it is not possible with the Quanta 4000 to control the temperature of the capillary and to automatically rinse the capillary with base without changing the outlet buffer. An experiment performed with other equipment (HP G1602A HPCE sys-

Table II. Repeatability expressed as relative standard deviation of migration times and peak areas from nine analyses of acid-precipitated casein using a hydrophilically coated and an untreated capillary, respectively. The values presented (expressed in \%) are mean values for the peaks for $\beta$-casein $A 1$ and $\alpha_{51}$-casein.

Répétabilité exprimée comme déviation standard relative des temps de migration et des aires de pic pour neuf analyses de caséine acide avec un capillaire traité par un polymère hydrophile et un capillaire non traité, respectivement. Les taux présentés (exprimés en \%) sont les moyennes pour les pics de caséine $\beta A 1$ et de caséine $\alpha_{s l}$.

\begin{tabular}{lcc}
\hline Parameter & Coated & Untreated \\
\hline Migration time & 1.9 & 1.9 \\
Relative migration time $^{\mathrm{a}}$ & 0.4 & 0.6 \\
Peak area $^{\text {Normalised peak area }}{ }^{\mathrm{b}}$ & 8.2 & 7.0 \\
Peak height & 0.0 & 5.6 \\
& & 3.7 \\
\hline
\end{tabular}

a Relative to the reference compound. ${ }^{b}$ Peak area divided by migration time.

${ }^{a}$ Relatif au composé de référence. ${ }^{\mathrm{b}}$ Aire de pic divisé par temps de migration. tem, Hewlett-Packard A/S, Waldbronn, Germany) at a constant outer capillary temperature of $30{ }^{\circ} \mathrm{C}$, and with extensive capillary wash between injections $(\mathrm{NaOH}$ for $2 \mathrm{~min}$, followed by water for $2 \mathrm{~min}$ and finally buffer for $3 \mathrm{~min}$ ) gave an RSD value of $2.7 \%(n=9)$ for the normalized peak area of $\beta$-casein A 1 in a UF-Feta cheese sample. This value is similar to the values obtained by de Jong et al (1993) for caseins in milk.

The performance of the untreated capillary was further studied with respect to linearity of the detector response vs injection time and sample concentration, respectively. The injection linearity was satisfactory over almost one decade of injection time ( 5 to $40 \mathrm{~s}$ ) with $r^{2}>0.996$ (not shown). A linearity plot of peak area/injection time vs injection time (Dorschel et al, 1989) showed a true linearity for $\alpha_{s 1}$-and $\beta$-casein within the $10-40$-s interval with a tolerance of $\pm 3 \%$ (not shown).

The correlation between $\alpha_{\mathrm{s} 1}$-casein or $\beta$-casein A1 concentration in standard samples and resulting peak area in the electrophoregrams was almost linear (fig 8A). The linearity plots (peak area/concentration vs concentration) show that all sensitivity values were close to the interval representing $95 \%$ to $105 \%$ of the mean value (dotted lines in fig 8B). Use of corrected peak areas (area divided by migration time) instead of simple peak areas did not change the linearity values.

Provided that the recovery of caseins in different cheese matrices is satisfactory the CE method presented, with improved repeatability on peak areas and with assessment of necessary reductant concentration and reaction time, might be used to quantitatively follow the breakdown of all major caseins and the formation of primary degradation products in cheese. The only exception is $\alpha_{\mathrm{s} 1}$-casein in cases where $\gamma_{1}$-casein is being formed. 


\section{CONCLUSION}

The four different bovine caseins were well separated by $C E$ in coated and untreated capillaries under the present conditions using HPMC as the polymeric additive. Further, at least two genetic variants of $\beta$-casein, A1 and $A 2$, were separated as were the two phosphorylation stages of $\alpha_{\mathrm{s} 1}$-casein and four phosphorylation stages of the $\alpha_{\mathrm{s} 2}$-casein monomer.

The major degradation product of $\alpha_{\mathrm{s} 1}$-casein formed by the action of chymosin, $\alpha_{\mathrm{s1}}$-casein-I, was separated from $\alpha_{\mathrm{sl}}$-casein and from all other major caseins in the cheeses examined. The major degradation products of $\beta$-casein with plasmin, $\gamma$-caseins, were migrating well ahead of the $\beta$-caseins but in the area of the $\alpha_{\mathrm{s}}$-caseins. The two peptides resulting from the chymosin catalysed cleavage of $\kappa$-casein, para$\mathrm{K}$-casein and caseinomacropeptide, migrated in front of and behind the intact caseins, respectively, and did not interfere with other caseins. Thus, in the absence of $\beta$-casein degradation, all major casein components in cheese should be determinable in one analysis.

The repeatability of the migration time calculated relative to the migration time of a reference compound was good. With minor improvements and validation, the $\mathrm{CE}$ method presented might be used for quantitative assessment of casein degradation in cheeses. Furthermore, the extraction procedure for cheeses, including UF-cheeses and cheeses containing denatured whey proteins, can be simplified by use of the citrate solution of the cheese without acid precipitation of the caseins.

The CE method presented is considered to be superior to urea-PAGE and an attractive alternative or supplement to existing
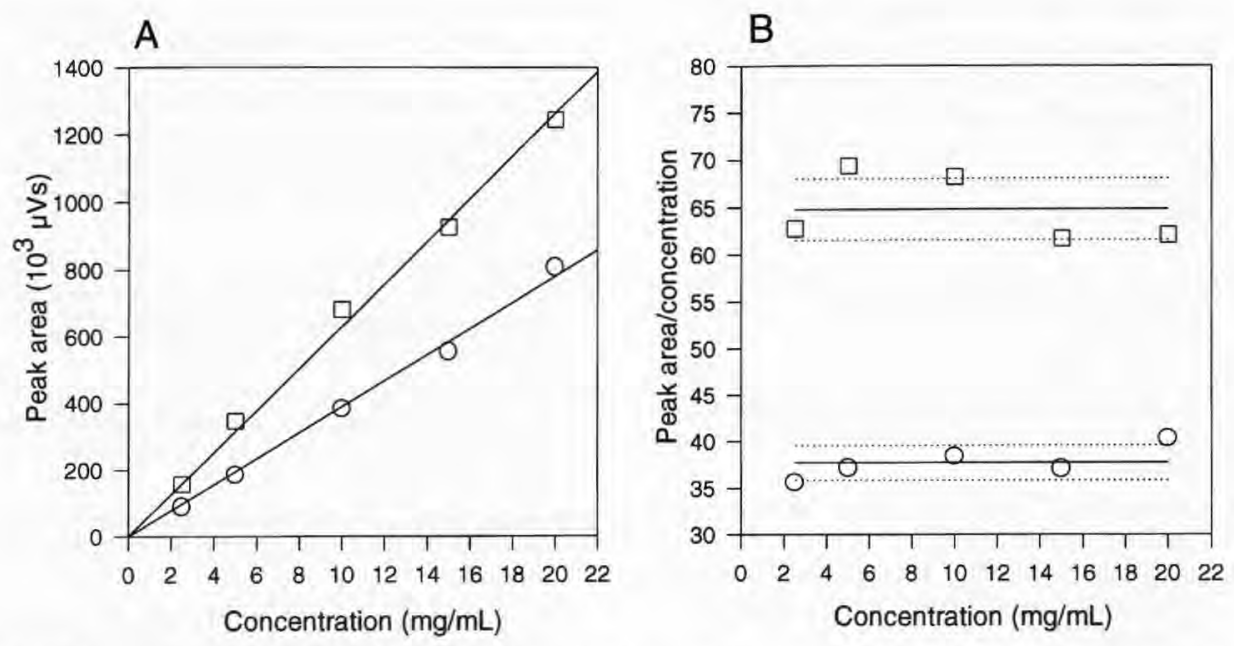

Fig 8. Linearity of the method assessed with purified caseins using an untreated capillary. A. Peak area as function of concentration of caseins. B. Linearity plot of the data in A. $\square$ : $\beta$-casein A1, $\bigcirc: \alpha_{\mathrm{s} 1}$-casein. Other conditions as described in the Methods section.

Linéarité de la méthode avec des caséines purifiées et un capillaire non traité. A. Aire de pic en fonction de la concentration de caséine. $\boldsymbol{B}$. Courbe de linéarité des données montrées en $\boldsymbol{A}$. $\square$ : caséine $\beta A I$; $O$ : caséine $\alpha_{s I}$. Autres conditions : comme décrites dans la section 'Méthodes'. 
HPLC methods for determination of proteolysis in cheese.

\section{ACKNOWLEDGMENTS}

The authors are most grateful to LK Rasmussen, the Protein Chemistry Laboratory, University of Aarhus, Denmark, for provision of pure casein standards, to D Chatterton, MD Foods Ingredients, Denmark, for provision of caseinomacropeptide and to J Hermansen, the National Institute of Animal Science, Department of Research in Cattle and Sheep, Research Centre Foulum, Denmark, for providing samples of fresh milk with specified casein variants. Thanks are also extended to $\mathrm{H}$ Wium and JS Madsen, Department of Dairy and Food Science, The Royal Veterinary and Agricultural University, Denmark, for placing cheese samples at our disposal. The work was financed by The Danish Ministry of Agriculture.

\section{REFERENCES}

Andrews AT, Taylor MD, Owen AJ (1985) Rapid analysis of bovine milk proteins by fast protein liquid chromatography. J Chromatogr 348, 177-185

Calvo MM, Leaver J, Law AJR, Banks JM (1992) Analysis of caseins in cheese using ion-exchange chromatography. Milchwissenschaft 47, 417-419

Centeno J, Rodrigez-Otero JL, Cepeda A (1994) Changes in the protein profile of Arzua cheese (NW Spain) during ripening. Milchwissenschaft 49 , 319-322

Chen FTA, Zang JH (1992) Determination of milk proteins by capillary electrophoresis. J AOAC Int 75, 905-909

Christensen TMIE, Kristiansen KR, Madsen JS (1989) Proteolysis in cheese investigated by high performance liquid chromatography. I Dairy Res 56 , $823-828$

Creamer LK (1991) Electrophoresis of cheese. Bull Int Dairy Fed 261, 14-28

Creamer LK, Olson NF (1982) Rheological evaluation of maturing Cheddar cheese. J Food Sci 47 , 631-636, 646

de Jong N, Visser S, Olieman C (1993) Determination of milk proteins by capillary electrophoresis. J Chromatogr 652, 207-213

Dorschel CA, Ekmanis JL, Oberholtzer JE, Warren FV, Bidlingmeyer BA (1989) LC detectors: evaluation and practical implications of linearity. Anal Chem 61, 951A-968A
Elfagm AA, Wheelock JV (1978) Heat interaction between $\alpha$-lactalbumin, $\beta$-lactoglobulin and casein in bovine milk. I Dairy Sci 61, 159-163

Exterkate FA, Alting AC (1995) The role of starter peptidases in the initial proteolytic events leading to amino acids in Gouda cheese. Int Dairy I 5, 15-28

Fox PF, Law J, McSweeney PLH, Wallace J (1993) Biochemistry of cheese ripening. In: Cheese: Chemistry, Physics and Microbiology. Vol 1. General Aspects 2nd edn (Fox PF, ed) Chapman and Hall. London, 389-438

Grappin R, Rank TC, Olson NF (1985) Primary proteolysis of cheese proteins during ripening. A review, I Dairy Sci 68, 531-540

Grappin R, Ribadeau-Dumas B (1992) Analytical methods for milk proteins. In: Advanced Dairy Chemistry 1. Proteins (Fox PF, ed) Elsevier, London, $1-62$

Grossman PD, Colburn JC, Lauer HH, Nielsen RG. Riggin RM, Sittampalam GS, Rickard EC (1989) Application of free-solution capillary electrophoresis to the analytical scale separation of proteins and peptides. Anal Chem 61, 1186-1194

Hoagland PD, Thompson MP, Kalan EB (1971) Amino acid composition of $\alpha_{3_{3}}, \alpha_{54^{-}}$, and $\alpha_{5}$-caseins. J Dairy Sci 54, 1103-1110

Hollar CM, Law AJR, Dalgleish DG, Brown RJ (1991) Separation of major casein fractions using cationexchange fast protein liquid chromatography. J Dairy Sci 74, 2403-2409

Kanning M, Casella M, Olieman C (1993) Milk and soy protein analysis using capillary zone electrophoresis. LC-GC Int 6, 701-706

Kristiansen KR, Otte J, Zakora M, Qvist KB (1994) Capillary electrophoresis used to monitor the enzymatic hydrolysis of caseins and the fractionation of hydrolysis products. Milchwissenschaft 49 . 683-688

Lindner H, Wurm M, Dirschlmayer A, Sarg B, Helliger W (1993) Application of high-performance capillary electrophoresis to the analysis of $\mathrm{H}_{1}$ histones. Electrophoresis 14, 480-485

McSweeney PLH, Fox PF, Olson NF (1995) Proteolysis of bovine caseins by cathepsin D: preliminary observations and comparison with chymosin. Int Dairy J 5, 321-336

Mulvihill DM, Fox PF (1979) Proteolytic specificity of chymosin on bovine $\alpha_{\mathrm{s} 1}$-casein. I Dairy Res 46 , 641-651

Ng-Kwai-Hang KF, Chin D (1994) Semipreparative isolation of bovine casein components by high-performance liquid chromatography. Int Dairy $J 4$. $99-110$

Otte JAHJ, Kristiansen KR, Zakora M, Qvist KB (1994) Separation of individual whey proteins and measurement of $\alpha$-lactalbumin and $\alpha$-lactoglobulin by capillary zone electrophoresis. Neth Milk Dairy J 48, 81-97 
Otte J, Midtgaard L, Qvist KB (1995) Analysis of caseinomacropeptide(s) by free solution capillary electrophoresis. Milchwissenschaft 50, 75-79

Rasmussen LK, Petersen TE (1991) Purification of disulfide-linked $\alpha_{\mathrm{s} 2}$ - and $\kappa$-casein from bovine milk. J Dairy Res 58, 187-193

Rasmussen LK, Højrup P, Petersen TE (1992a) The multimeric structure and disulfide-bonding pattern of bovine K-casein. Eur J Biochem 207, 215-222

Rasmussen LK, Højrup P, Petersen TE (1992b) Localization of two interchain disulfide bridges in dimers of bovine $\alpha_{\mathrm{s} 2}$-casein. Eur J Biochem 203, 381-386

Strange ED, Van Hekken D, Thompson MP (1991) Qualitative and quantitative determination of caseins with reverse-phase and anion-exchange HPLC. $J$ Food Sci 56, 1415-1420

Swaisgood HE (1992) Chemistry of the caseins. In: Advanced Dairy Chemistry 1. Proteins (Fox PF, ed) Elsevier, London, 63-110
Syväoja EL (1992) Quantitative determination of the main casein components and purification of $\alpha_{\mathrm{s1}}$ and $\kappa$-casein from bovine milk. Milchwissenschaft 47, 563-566

van Hekken DL, Thompson MP (1992) Application of PhastSystem ${ }^{\circledR}$ to the resolution of bovine milk proteins on urea-polyacrylamide gel electrophoresis. J Dairy Sci 75, 1204-1210

Visser FMW, de Groot-Mostert AEA (1977) Contribution of enzymes from rennet, starter bacteria and milk to the proteolysis and flavour development in Gouda cheese. 4. Protein breakdown: a gel electrophoretical study. Neth Milk Dairy J 31, 247-264

Werner WE, Demorest DM, Stevens J, Wiktorowicz JE (1993) Size-dependent separation of proteins denatured in SDS by capillary electrophoresis using a replaceable sieving matrix. Anal Biochem 212, 253-258 